equilibrium, though he also ascribes a specific stimulating effect to the bicarbonate ion. To the present author, it seems that this specific effect may be due entirely to the effect of the anion in determining the permeability of the tissues to the kation.

TABLE II.

\begin{tabular}{|c|c|c|c|c|c|c|c|}
\hline \multirow[b]{3}{*}{ Ex. } & \multirow[b]{3}{*}{ Salt. } & \multirow[b]{3}{*}{ Concn. } & \multirow{3}{*}{ 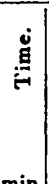 } & \multicolumn{3}{|c|}{ Sodium. } & \multirow[b]{3}{*}{ Remarks. } \\
\hline & & & & 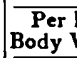 & $\begin{array}{l}\text { Kilo } \\
\text { Weight }\end{array}$ & & \\
\hline & & & & $\begin{array}{l}\text { Injec. } \\
\text { Gr'ms }\end{array}$ & $\left|\begin{array}{l}\text { Re- } \\
\text { tained } \\
\text { Gr'ms }\end{array}\right|$ & $\begin{array}{l}\text { Per } \\
\text { roocc. } \\
\text { Plas- } \\
\text { ma. }\end{array}$ & \\
\hline I & $\mathrm{NaHCO}_{3}$ & 0.9 & $\begin{array}{l}38 \\
44\end{array}$ & $\begin{array}{l}0.694 \\
0.83 \mathrm{I}\end{array}$ & $\left|\begin{array}{l}0.493 \\
0.631\end{array}\right|$ & $\begin{array}{l}442 \\
447\end{array}$ & $\begin{array}{l}\text { Twitching. } \\
\text { Convulsions. }\end{array}$ \\
\hline 5 & $\mathrm{NaHCO}_{2}$ & 0.9 & 40 & 0.747 & 0.730 & 436 & Twitching. \\
\hline 2 & $\mathrm{NaHCO}_{3}$ & 0.9 & 43 & 0.783 & 0.684 & 514 & $\begin{array}{l}\text { Twitching. Injected soln. contained } \\
\text { O.I equivalent of } \mathrm{K}, \mathrm{Mg} \text { and } \mathrm{Ca} \text {. }\end{array}$ \\
\hline 3 & $\mathrm{NaHCO}_{3}$ & 0.9 & 40 & 0.793 & 30.709 & 457 & $\begin{array}{l}\text { Convulsions. Injected soln. con- } \\
\text { tained I.o equivalent of } \mathrm{K}, \mathrm{Mg} \\
\text { and Ca. }\end{array}$ \\
\hline 4 & $\mathrm{NaHCO}_{2}$ & 0.47 & 68 & 1.140 & 0.87 & 420 & $\begin{array}{l}\text { No twitching or tremor. Death due } \\
\text { to respiratory failure. }\end{array}$ \\
\hline 5 & $\mathrm{NaCl}$ & $0.60^{1}$ & 35 & 1.45 & I.30 & 493 & Convulsions. \\
\hline 6 & $\mathrm{Na}_{2} \mathrm{NPO}_{4}$ & $0.38^{1}$ & 33 & 0.70 & 0.62 & $45 \mathrm{I}$ & $\begin{array}{l}\text { No twitching. Death due to respir- } \\
\text { atory failure. }\end{array}$ \\
\hline 8 & $\mathrm{Na}_{2} \mathrm{SO}_{4}$ & $0.25^{1}$ & I I I l & $|\mathrm{I} .29|$ & To.82 & 480 & Twitching. \\
\hline
\end{tabular}

II 5 (I697)

The peptolytic enzymes of hemolytic streptococci; methods.

By RANDOLPH WEST and FRANKIIN A. STEVENS.

[From the Medical Clinic of the Presbyterian Hospital, Columbia University, New York City.]

During the study of the virulence of hemolytic streptococci, it has been necessary to understand the action of the cocci on certain protein fractions. On account of the structure of these bacteria, the methods required to obtain the active proteolytic substance from the bacterial cell, and to accomplish the sterilization of the solution containing the enzyme were at first consuming and laborious. With the procedure outlined active

1 These figures represent the average concentration. More dilute solutions were employed at first and more concentrated ones later. See protocols in Greenwald, Journal of Pharmacology and Experimental Therapeutics, 1918, xi, 281. 
solutions may be obtained without difficulty. All procedures were sterile. Beef infusion has been used as a base for the media. It has been prepared in the usual way except for the addition of $0 . I$ per cent. dextrose. After the ingredients were dissolved in the infusion, the broth was titrated to $P_{H} 8.5$ or 9.0 and boiled until the phosphates were precipitated out. It was then filtered, adjusted to $P_{\mathrm{H}} 8.0$ and autoclaved. Precipitation during the sterilization was avoided by the preliminary boiling in alkaline solution. The glucose was apparently not decomposed to an extent sufficient to interfere with the growth of the bacteria. The acidity developed in the growth of the culture (about $P_{H}$ 6.5) causes the spontaneous agglutination of the streptococci, yet it is not detrimental to the production or the life of the enzyme.

Flasks of $6 \mathrm{~L}$. volume were seeded with a broth culture of Strain Py 3, a beta type streptococcus of human origin. After 12 hours, the clear supernatant broth was decanted by siphon and the agglutinated streptococci were centrifuged, washed repeatedly in physiological salt solution and resuspended in 15 c.c. of $M / 15$ phosphate of $P_{H}$ 7.o. They were then dried in an agate mortar in vacuum after the addition of 2 grams of powdered glass. Grinding was carried out until there was a minimum amount of Gram positive material in the smear. When they were well macerated, the bacterial mass was taken up in 50 c.c. of distilled water, and allowed to stand under toluol at Io degrees C. for 12 to 24 hours. The fluid pipetted from beneath the layer of toluol was centrifuged. It contained the active enzyme and was sterile. The sediment contained no demonstrable peptolytic substance.

The substrate used in the experiments was a I per cent. solution of peptone prepared especially for this work by Fairchild Bros. and Foster; this peptone contained 12.5 per cent. nitrogen of which approximately one fifth could be determined as amino nitrogen according to Van Slyke. The solutions of peptone were sterilized in the Arnold sterilizer. To determine the effects of $\mathrm{H}$-ion concentration, heat and enzyme concentration series of 20 c.c. volumetric flasks were prepared with the enzyme, $M / 15$ buffer mixtures (phosphate or citrate) and sufficient substrate to bring the final concentration to I.O per cent. Duplicate flasks with boiled enzyme served as a control for each determination 
of the series. After incubation at 37 degrees for 48 hours, the sterility of the experiments was proven by broth cultures and the increase in amino $\mathrm{N}$ determined by the micro apparatus.

The increase in amino nitrogen with various enzyme preparations has varied from 14 to $26 \mathrm{mg}$. per cent. By varying the $\mathrm{H}$-ion concentration of the solutions a maximum activity was found at $P_{H} 7.0$ with a decrease on both the alkaline and acid sides of neutrality. The acid endpoint of activity was about $P_{H} 4.5$. It was further found that heat destroyed the enzyme very readily. At a temperature of $56^{\circ} \mathrm{C}$. for ten minutes in the absence of substrate, the enzyme deteriorated to such an extent that only a few mg. of amino nitrogen were obtained by its action. Higher temperatures completely destroyed it. Concentration curves at the optimum $\mathrm{H}$-ion concentration approximated the usual curves for enzymes.

$$
\text { II } 6 \text { (1698) }
$$

A study of the Wassermann reaction in one hundred and forty cases of diabetes mellitus.

By JACOB ROSENBLOOM.

In a study of one hundred and forty cases of diabetes mellitus, a positive Wassermann reaction was found in sixteen cases. Eight of these sixteen cases presented signs of tertiary syphilis. These eight cases were treated for the existing syphilis. There was no increase in tolerance for carbohydrate following the treatment. This may be due to the fact that the fibrosis of the pancreas produced by the syphilis is not changed by the treatment.

$$
117 \text { (1699) }
$$

\section{Blood pressure studies in one hundred and forty cases of diabetes mellitus.}

\section{BY JACOB ROSENBLOOM.}

Blood pressure estimations were carried out on one hundred and forty cases of diabetes for varying lengths of time. Some of these cases have been studied for a period as long as ten years. On the basis of these studies it may be concluded that the blood 